(1) 1992 ISIJ (1/1/4/1/1/4/1/4

論 文

"llll/llllllill"

\section{レニウムを含むニッケル基単結晶超合金の 組織と合金元素の分配比}

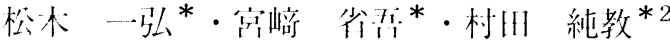 \\ 森永 正亲*3・晹川 夏夫*2
}

\title{
Microstructures and Partitioning Ratios of Alloying Elements in Rhenium Containing Nickel-based Single Crystal Superalloys
}

\author{
Kazuhiro Matsugi, Shogo Miyazaki, Yoshinori Murata, \\ Masahiko Morinacis and Nalsuo Yukawa
}

\begin{abstract}
Synopsis :
In order to obtain some criteria for determining the optimum compositions of rhenium(Re) containing nickel hased single crystal superalloys. the phase stability and the partition ratios of alloying elements between $\gamma$ and $\gamma^{\prime}$ phases were investigated using the $\mathrm{Ni}-10 \mathrm{Cr}-12 \mathrm{Al}-1.2 \mathrm{Ti}-2.6 \mathrm{Ta}-2.0 \mathrm{~W}-0.7 \mathrm{Mo}-0 \sim 1 \mathrm{Re}$ $(\mathrm{mol} \%)$ alloys. Most of Re atoms were found to be distributed mainly in the $\gamma$ phase and alter significantly the partition ratios of the other elements between $\gamma$ and $\gamma^{\prime}$ phases. It was shown that the decrease of $\mathrm{Cr}$, Ta, $\mathrm{W}$, Mo contents and the increase of $\mathrm{Al}$ content were most desirable in the design of alloys containing more than $0.25 \mathrm{~mol} \%$ Re. Further, in order to investigate the possibility Co addition into the Re containing alloys, its effects on the phase stability and the partition ratios of elements were examined with the $\mathrm{Ni}-10 \mathrm{Cr}-12 \mathrm{Al}-1.5 \mathrm{Ti}-2.1 \mathrm{Ta}-2.3 \mathrm{~W}-\left(1.8 \mathrm{Mo}-0.25 \mathrm{Re}\left(\mathrm{mol}^{\circ} \%\right)\right.$ alloys in which $0-9 \mathrm{~mol} \%(\%$ was substituted for $\mathrm{Ni}$. It became evident from the present experiment that the Co substitution for $\mathrm{Ni}$ did not induce any large changes in the phase stability and also in the partition ratios of the alloying elements in this system. Key words: Nickel based-single crystal superallows; Re containing superalloys; phase stability; partition ratio; alloy design.
\end{abstract}

\section{1. 緒}

\section{言}

萝考らはこ札まで。ガス夕ービンや゙ェットエンジン

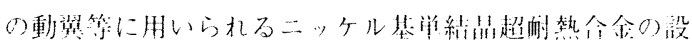

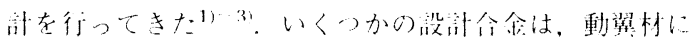

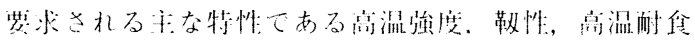

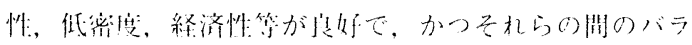

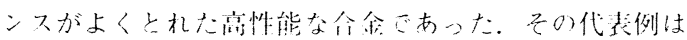
$\mathrm{Ni} 10 \mathrm{Cr}-12 \mathrm{Al}-\mathrm{Ti}-\mathrm{Ta}-\mathrm{W}-\mathrm{Mo}_{0}-0.25 \mathrm{Re}(\mathrm{mol} \%)$ の) 8 元系

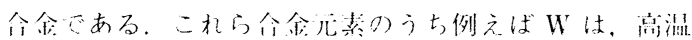

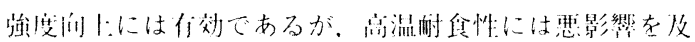

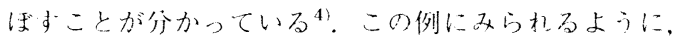

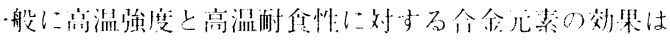

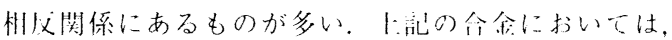

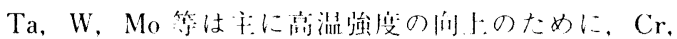

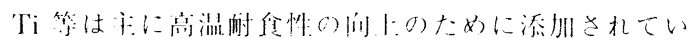

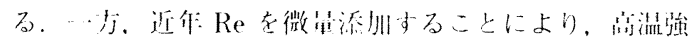

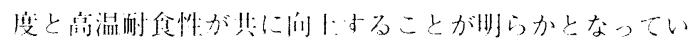

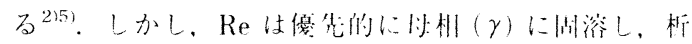

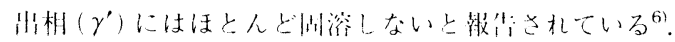

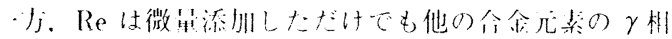

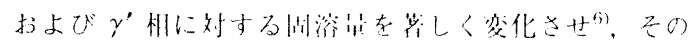

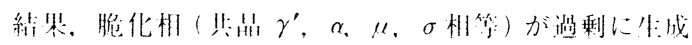

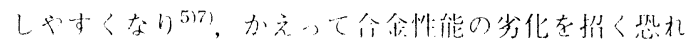

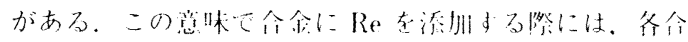

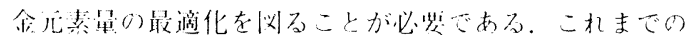

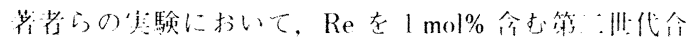
金で南万PWA1484 では、1313 K, $137 \mathrm{MPa} の$ 条件 で行ったクリーブ破断,験後に $\alpha(\operatorname{Re}, W 、$ Cr, Mo,

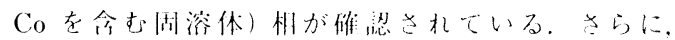

成 3 年 5 月 23 月受付 (Received May 23.1991)

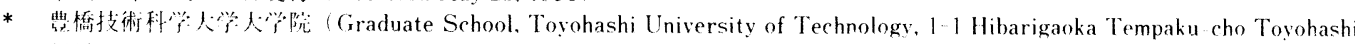
441)

*2㤟橋技術科学大兴 1. 博 (Toyohashi University of Technology)

*3豊橋技術科学大学: Ph. I). (Toyohashi University of Technology) 
CMSX $-4^{9)}$ では, 溶休化熱処理後においても体積率で $1 \%$ 程度の其昆 $\gamma^{\prime}$ 相が残留した。従って，これら命金

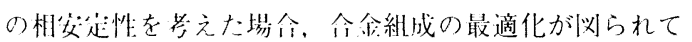
いるとは上小難い3).

合金組成の最適化を率るためにはRe 添加合金におけ る齐合全元素の分配比(齐合金元素が $\gamma$ 相と $\gamma^{\prime}$ 相に固 溶寸る割令) 存把据することが必荌不仃欠である。しか し Reに開する分酒比については，これまで信頼できる

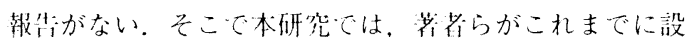
胡した $\mathrm{Ni}-10 \mathrm{Cr}-12 \mathrm{Al}-1.2 \mathrm{Ti}-2.6 \mathrm{Ta}-2.0 \mathrm{~W}-0.7 \mathrm{Mo}(\mathrm{mol} \%)$ 今金. (TUT101, Toyohashi University of Technology's

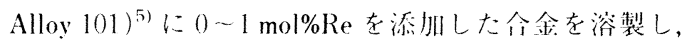

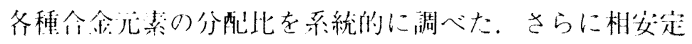
性について検咕老㞦之，Re 在会む高性能合金を開発す るために必塄な今全組成の聂滴化のための基本指針を得 ることを目的とした。

また二ッケル基超合金の諸特性に及ほす Co の影 響は, NASA の COSAM (Conservation of Strategic Aerospace Materials) 計润等10)11)で多くの研究がなさ れたにもかかわらず，まだ十分には解明されていない。 そこで著考らがこれまでに没湖した介金のうち，代表的 な奌州能介金である $\operatorname{Re}$ 添川の $\mathrm{Ni}-10 \mathrm{Cr}-12 \mathrm{Al}-1.5 \mathrm{Ti}-$ $2.1 \mathrm{Ta}-2.3 \mathrm{~W}-0.8 \mathrm{Mo}_{0}-0.25 \mathrm{Re}(\mathrm{mol} \%)$ 今金 $(\mathrm{TUT} 92)^{2)} に, 0$. 4.5. 9.0 mol\%Co t在添加して，相安分性と条介全元素 の分配比を淍べた。それらを基に Re 添加命金の組成の 最適化という觀点から，Coの效果について検䞑した。

\section{2. 実 験 方 法}

\section{$2 \cdot 1$ 試料の調整}

$2 \cdot 1 \cdot 1$ 試料

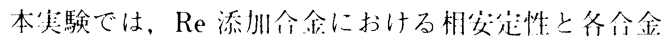
元素の分配比を検㗅するために、これまでに著者らが設 什した今金 TUT101 ( Ni-10Cr-12Al-1.2Ti-2.6Ta-2.0 W-0.7Mo, mol\%) の $\mathrm{Ni} \operatorname{Re}$ でそれぞれ0, 0.25 , $0.40,0.50,1.00 \mathrm{~mol} \%$ ずつ㯰換した 5 種の合金を用い たここれらの紬成を Table 1 にホすす。

また組成の最適化という観点から，Re 含有合金に打 けるCo の添加效果老淍べるために，以前に著者らが設 咕し，高性能であった介金 TUT92 ( Ni-10 Cr-12Al-1.5 $\mathrm{Ti}-2.1 \mathrm{Ta}-2.3 \mathrm{~W}-0.8 \mathrm{Mo}-0.25 \mathrm{Re}, \mathrm{mol} \%) の \mathrm{Ni}$ を $\mathrm{Co}$ で それぞれ $0,4.5,9.0 \mathrm{~mol} \%$ ずつ菅換した 3 種の今食を 溶製した。こ机らの組成を Table 2 に亦す。

Table 1 と 2 に組成を少した尖験令食 8 種のメル

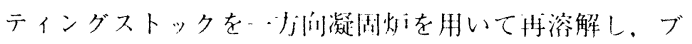
リッヂマン法で単絬早武料を溶製した。このときの周液
Table 1. Nominal compositions of alloys used for the present experiment on Re effects.

\begin{tabular}{ccccccccc}
\hline \multicolumn{8}{c}{ Composition, mol\% } \\
Alloy & $\mathrm{Ni}$ & $\mathrm{Cr}$ & $\mathrm{Al}$ & $\mathrm{Ti}$ & $\mathrm{Ta}$ & $\mathrm{W}$ & $\mathrm{Mo}$ & $\mathrm{Re}$ \\
\hline TUT101 & Bal. & 10 & 12 & 1.2 & 2.6 & 2.0 & 0.7 & \\
TUT201 & Bal. & 10 & 12 & 1.2 & 2.6 & 2.0 & 0.7 & 0.25 \\
TUT314 & Bal. & 10 & 12 & 1.2 & 2.6 & 2.0 & 0.7 & 0.40 \\
TUT321 & Baal. & 10 & 12 & 1.2 & 2.6 & 2.0 & 0.7 & 0.50 \\
TUT401 & Bal. & 10 & 12 & 1.2 & 2.6 & 2.0 & 0.7 & 1.00 \\
\hline
\end{tabular}

Table 2. Nominal compositions of alloys used for the present experiment on Co effects.

\begin{tabular}{lccccccccc}
\hline \multicolumn{10}{c}{ Composition, mol\% } \\
Alloy & $\mathrm{Ni}$ & $\mathrm{Cr}$ & $\mathrm{Al}$ & $\mathrm{Ti}$ & $\mathrm{Ta}$ & W & Mo & Re & Co \\
\hline TUT92 & Bal. & 10 & 12 & 1.5 & 2.1 & 2.3 & 0.8 & 0.25 & \\
TUT921A & Bal. & 10 & 12 & 1.5 & 2.1 & 2.3 & 0.8 & 0.25 & 4.5 \\
TUT921 & Bal. & 10 & 12 & 1.5 & 2.1 & 2.3 & 0.8 & 0.25 & 9.0 \\
\hline
\end{tabular}

界面の温度勾配 $(G)$ は $1.5 \times 10^{4} \mathrm{~K} / \mathrm{m}$, 引抜速度 $(R)$ は $2.8 \times 10^{-5} \mathrm{~m} / \mathrm{s}$ とした。試料寸法は, 直径 $1.1 \times$ $10^{-2} \mathrm{~m}$, 長さ $13 \times 10^{-2} \mathrm{~m}$ とした.

\section{$2 \cdot 1 \cdot 2$ 熱処理}

単結昆を溶製後, $1573 \mathrm{~K}$ で $14.4 \mathrm{ks}$ の溶体化熱処理 を施した。 その後, 原田らの用いた方法 ${ }^{12)} に$ 従って, $\gamma$ 相と $\gamma^{\prime}$ 相の沪衡化処理を以下の手順で䘕った。まず, 窒温でポンチにて局部的に加厂歪みを与えた後，1473 $\mathrm{K}$ で $252 \mathrm{ks}$ 加熱して， $\gamma$ 相と $\gamma^{\prime}$ 相の 2 相状態で再結晶 熱処理を施した，その後， $1313 \mathrm{~K}$ まで冷却速度 $3.3 \times$ $10^{-3} \mathrm{k} / \mathrm{s}$ で徐冷後, その温度で $4.3 \mathrm{Ms}$, 平衡化熱処理 を施し，承水中に焼き人れることにより急冷した。こ れらの処理によって局部歪みを尗たた筒所では， $\gamma$ 相と $\gamma^{\prime}$ 相が十分に粗火化したので，組成分析が精度よく行 えた。

\section{$2 \cdot 2$ 実験方法}

\section{$2 \cdot 2 \cdot 1$ 相安定性の評価}

实験会金の相安定性の評価は，(a)溶体化後の残留共 晶 $\gamma^{\prime}$ 相の量と, (b) $2 \cdot 1 \cdot 2$ 項で述べた平衡化熱処理後 に㧍ける脆化析出相 $(\alpha, \mu, \sigma$ 等) の有無を調べること により行ったこここで, 其晶 $\gamma^{\prime}$ 相の体積率については 画像解析装㯰（ニレコ LUZEX III）による面積分析法を 用いて求めた。脆化析出相の问蚠は, その電解抽出残渣 を微小部走查 X 線分析 (EPMA と略す) と X 線回折す

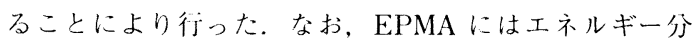
散法 (EDX と略す) を用いた。

$2 \cdot 2 \cdot 2 \gamma$ 相と $\gamma^{\prime}$ 相の組成分析

$2 \cdot 1 \cdot 2$ 項で述べた平衡化熱処理後の試料の $\gamma$ 相および $\gamma^{\prime}$ 相の組成を, EDX 装㯰を装着した EPMA 装㯰 (EPMA/EDX と略す) を用いて分析した。な扮, 分析 
条件は加速電圧が $20 \mathrm{kV}$, ビーム電流が $5 \times 10^{-10} \mathrm{~A}$ で あった。得られたスペクトルに対してZAF 法による補 正を行った。なお，ZAF 補正には各元素の純物質を標 準試料として用いた。

\section{3. 実験結果および考察}

\section{$3 \cdot 1 \mathrm{Ni}-10 \mathrm{Cr}-12 \mathrm{Al}-1.2 \mathrm{Ti}-2.6 \mathrm{Ta}-2.0 \mathrm{~W}-0.7 \mathrm{Mo}-0 / 0.25 /$ $0.40 / 0.50 / 1.00 \operatorname{Re}$ 合金}

$3 \cdot 1 \cdot 1$ 共晶 $\gamma^{\prime}$ 相

$\operatorname{Re}$ 含有量の異なる 5 種の合金 (Table 1) について, 単結晶試料の溶製のまま（As cast）および溶体化処理後 に求ける共晶 $\gamma^{\prime}$ 相量を測定した。その結果を Fig. 1 に 示す。 $\operatorname{Re}$ 添加にともなって, 共晶 $\gamma^{\prime}$ 相量は As cast 材および溶体化処理材ともに直線的に増加したここの結 果は $\operatorname{Re} の$ 極く微量添加によっても合金の相安定性が大

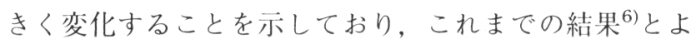
く一致している。一般に，共晶 $\gamma^{\prime}$ 相量を減じることに よりクリープ強度は向上することが報告されている 従って, As cast のような非平衡凝固状態で存在する共 晶 $\gamma^{\prime}$ 相は，溶体化処理によって消失させることが望ま しい. しかし, 溶体化後, $0.4 \mathrm{vol} \%$ 程度残留する微紼 其晶 $\gamma^{\prime}$ 相は，クリープ破断寿命にほとんど影響を与え ないことが,これまでの研究から分かっている ${ }^{31}$. 従っ て, $\operatorname{Re}$ を $\mathrm{Ni}$ のみで置換したこれら 8 元系合金におい て, 溶体化後に許容量以下の共晶 $\gamma^{\prime}$ 相量となる合金の $\operatorname{Re}$ 含有量は $0.25 \mathrm{~mol} \%$ 以下であることが分かる。本系 合金に Reを $0.25 \mathrm{~mol} \%$ より多く添加する際には, Re 以外の合金元素の量の最適化を四り，其晶 $\gamma^{\prime}$ 相を抑制

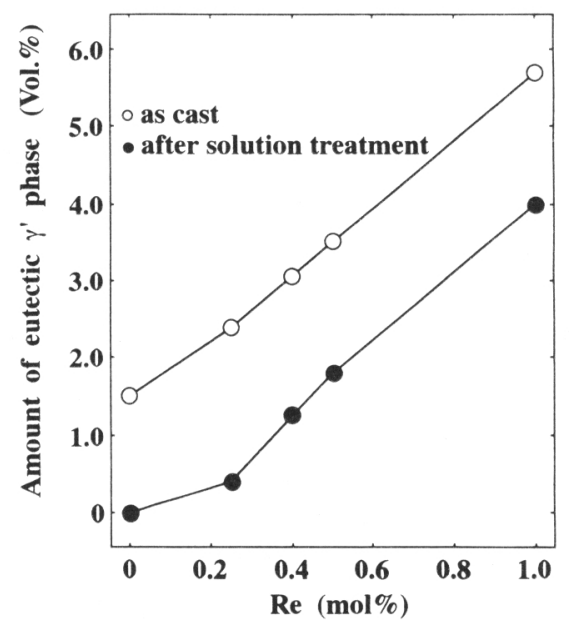

Fig. 1. Change in the amount of the eutectic $\gamma^{\prime}$ phase with the Re content of alloys.
しなければならない。

ところで $\mathrm{Al}$ や $\mathrm{Ta}$ 等の $\gamma^{\prime}$ 相形成元素は, それら元 素量の増加と共に $\gamma^{\prime}$ 相量が増加し, 結果として共晶 $\gamma^{\prime}$ 相量が増加することが知られている ${ }^{14)}$.このような例 に従えば，Fig. 1 の結果より， Reはあたかも $\gamma^{\prime}$ 相形 成元素であるかのように振る舞っているとみなせるかも しれない。しかし前述のように，これまで Reは $\gamma$ 相 に入ると報告されており ${ }^{6)}, \operatorname{Re}$ の役割については依然 として不明な点が多い

そこで，さらに凝固組織の各部について組成分析を 行った。すなわち 0 抢よび $0.5 \mathrm{~mol} \%$ Re を添加した合 金（TUT101 と 321）の As cast 材を用いて, デンドラ イトの中心部，デンドライトの狭間および共晶 $\gamma^{\prime}$ 相の 組成分析を EPMA/EDX によって行った。TUT321の 組成分析に用いた試料の代表例を Photo. 1 に示す。そ の分析結果を Fig. 2 Fig. 4 に示す. Re の有無にかか わらず $\mathrm{Ni}, \mathrm{W}$ はデンドライトの中心部に, $\mathrm{Al}, \mathrm{Cr}$, $\mathrm{Ta}, \mathrm{Ti}, \mathrm{Mo}$ はデンドライトの狭間に平均組成より多く 分布していた。一方, Fig. 2，3 加分かるように Re はデンドライトの中心部に多くみられた。合金を融液か ら冷却した場合，まず $\gamma$ 相の晶出が起こる．従って, デンドライトの中心部は， $\gamma$ 相形成元素に富んでいる. この結果は上述の予想とは異なり, Re は $\gamma^{\prime}$ 相形成傾 向を持たず，むしろ $\gamma$ 相形成元素であると言える。そ れにもかかわらず, Re 添加と共に Fig. 1 に示したよう に，其晶 $\gamma^{\prime}$ 相が単調に増加したことはたいへん興味深 い。これらの結果は $\operatorname{Re}$ が各種合金元素，特に $\gamma^{\prime}$ 相形 成元素の $\gamma$ 相と $\gamma^{\prime}$ 相への分配量を変化させ, 結果とし て其晶 $\gamma^{\prime}$ 相を増加させたと考えることができる。事 実, Fig. 2 にみられるようにデンドライトの中心部では

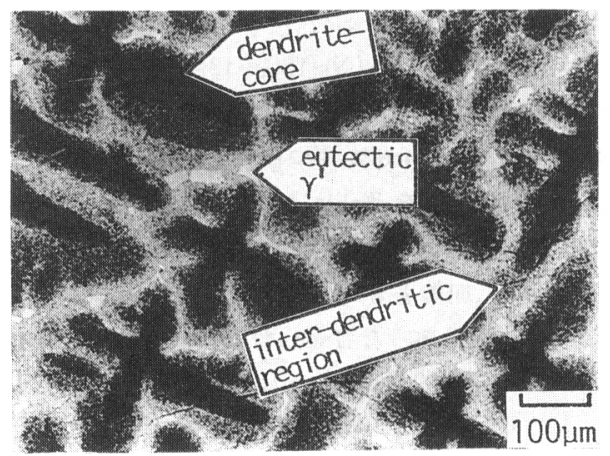

Photo. 1. A microstructure of TUT 321 obtained as cast state, showingthesizes of the dendritecore, inter-dendritic region and eutectic $\gamma^{\prime}$ phase for analyzing their compositions by EPMA. 


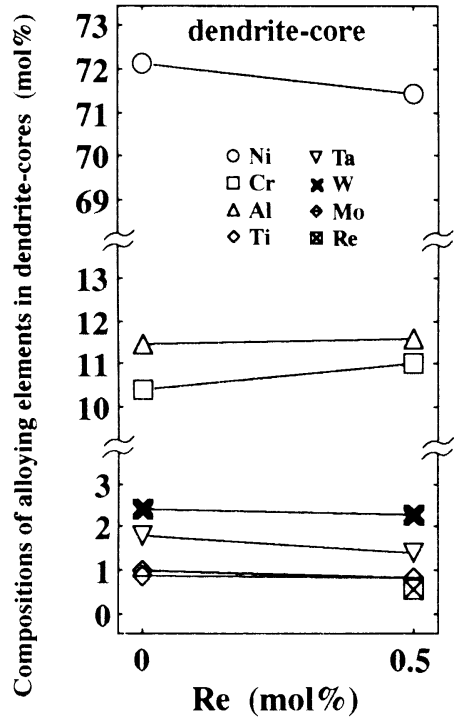

Fig. 2. Compositional change in the dendrite -cores with the Re content of alloys.

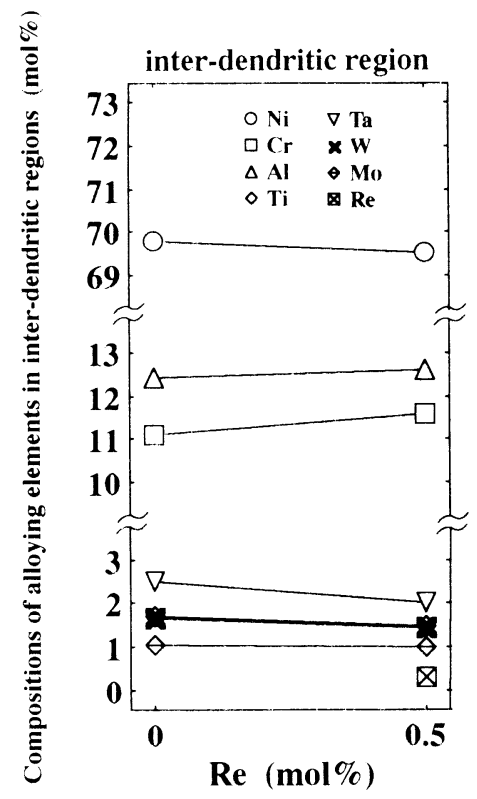

Fig. 3. Compositional change in the inter-dendritic regions with the Re content of alloys.

$\operatorname{Re}$ 添加により, $\mathrm{Cr}$ が増㞦し $\mathrm{Ni}$ と $\gamma^{\prime}$ 相形成元素であ る Ta が減少する傾们を示している。このデンドライト の中心部では Ta 以外の $\gamma^{\prime}$ 相形成元素の量は変化せ ず，Ta 量のみの減少が贸められた。一方，デンドライ

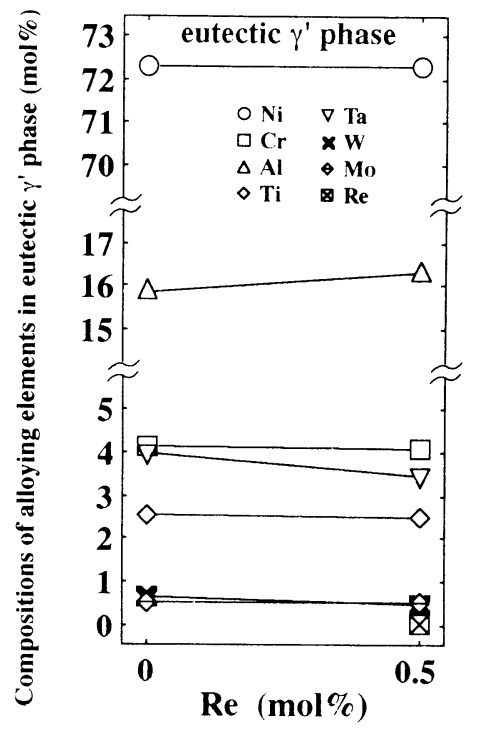

Fig. 4. Compositional change in the eutectic $\gamma^{\prime}$ phase with the Re content of alloys.

トの狭間でも Re 添加舍金では, $\mathrm{Cr}$ が増加し Ni と Ta が減少した (Fig. 3)。さらに Fig. 4にみら机るように 其荘 $\gamma^{\prime}$ 相に扔いても $\mathrm{Ta}$ の減少と $\mathrm{Al}$ の増加が想めら れ，その他の合全元素の量は Re 添加によってもほとん ど変化していない。これらの事璂は $\operatorname{Re} の$ 添加により $\gamma$ 相と $\gamma^{\prime}$ 相の閒の相潮が变化し, 各介金儿素の分配に 変化を来したことを示している，特に著しい変化をした $\gamma^{\prime}$ 相形成元素の Taは其蒋 $\gamma^{\prime}$ 棚に濃化するのではなく

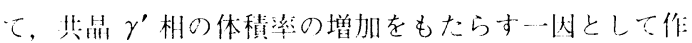
朋したものと考えられる。

$3 \cdot 1 \cdot 2$ 脆化析计相

0 および $0.25 \mathrm{~mol} \% \mathrm{Re}$ 添加の TUT101，201には其荘 $\gamma^{\prime}$ 相以外の脆化相は確認されなかったが, $0.40,0.50$ および $1.00 \mathrm{~mol} \% \operatorname{Re}$ 添加の TUT314，321 および 401 には，壮衡化時效処理後に $\alpha(\mathrm{W}, \mathrm{Cr}, \mathrm{Mo}, \operatorname{Re}$ を会む

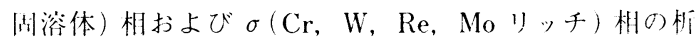
岄が琶められた。 TUT314に析出した $\alpha$ および $\sigma$ 相を

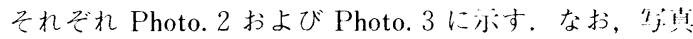
中にはそ机らの構成元素の線分析結果も併せて亦す。 こで， $\alpha$ 相中の $\operatorname{Re}$ 量は今金の平均組成よりも多かった ものの微量であったため，W 等の線分析と比較するこ とは不叮能なので Reの線分析結果は示さなかった。

ナ， $\sigma$ 相中の Mo の線分析によるプロファイルはRe それとほほ同様であったので，Photo. 3 においてはRe の線分析で代表させた。 


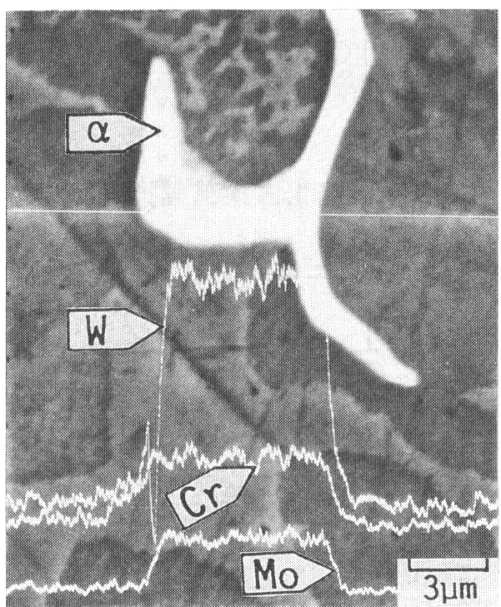

Photo. 2. A SEM image, showing the $\alpha$ phase precipitated in TUT 314 alloy after the homogenization-heat treatment.

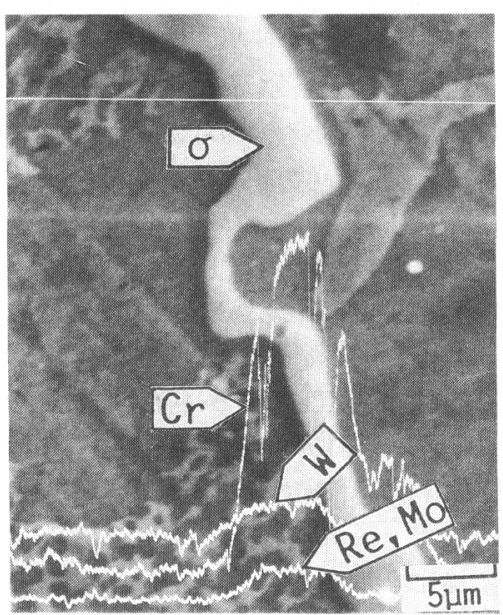

Photo. 3. A SEM image, showing the $\sigma$ phase precipitated in TUT 314 alloy after the homogenization-heat treatment.

このように，Ret存 $\mathrm{Ni} の$ みで置換した本 8 元系全金 では, $0.40 \mathrm{~mol} \%$ 未満の $\operatorname{Re}$ 添加合金においてのみ脆化 析出相の生成を抑制できる。従って，共晶 $\gamma^{\prime}$ 相および 脆化析出相の生成老共に抑制して相安定性を良好に保つ ためには, Ni-10Cr-12Al-1.2Ti-2.6 Ta-2.0W-0.7Mo-Re $(\mathrm{mol} \%)$ 合金中の $\operatorname{Re}$ 添加量を $0.25 \mathrm{~mol} \%$ 以下にしなけ ればならない。

$3 \cdot 1 \cdot 3 \gamma, \quad \gamma^{\prime}$ 相の組成と合金元素の分配比

しかしながら，上述したように $\operatorname{Re} は$ 合全元素の $\gamma$ 相と $\gamma^{\prime}$ 相への分配量を変化させるので，各命金元素量

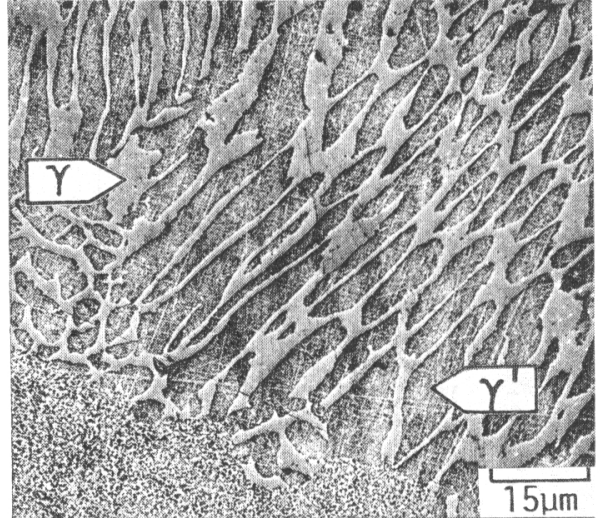

Photo. 4. A SEM image, showing the coarsened $\gamma$ and $\gamma^{\prime}$ phases for EPMA analysis (TUT 201).

の最適化を网ることによって，相安定性を崩すことなく Re 添加量を増加し合金特性を向上させ得る叮能性があ る。そこで，まず $\operatorname{Re}$ 添加合金における各合金元素の 分配比を把握するため,Table 1 に組成を示した合金 （TUT101，201，314，321）の $\gamma$ 相拉よび $\gamma^{\prime}$ 相の組成 存EPMA/EDXにより分析した. $2 \cdot 1 \cdot 2$ 項で説明した方 法で粗大化させた $\gamma$ 相および $\gamma^{\prime}$ 相の代表例を Photo. 4 に示吉。このように $\gamma$ 相㧍よび $\gamma^{\prime}$ 相は EPMAの分解 能で十分正確な分析ができる程度に粗大化していること が分かる。 $\gamma$ 相扮よび $\gamma^{\prime}$ 相の分析結果を，それぞれ Fig. 5 およびFig. 6 に示す。全金元素のうち Cr, W, Mo, Reは $\gamma$ 相に, Ni, Al, Ta, Ti は $\gamma^{\prime}$ 相に多く分 配した。この結果は上述したように， Reが $\gamma$ 相形成傾 们在持つという事実と一致している。 $\gamma$ 相では， Re 添 加にともない $\mathrm{Cr}, \mathrm{W}$ 量が減少し, $\mathrm{Ni}, \mathrm{Al}, \operatorname{Re}$ 量が増 加したこの結果は Reを $0.40 \mathrm{~mol} \%$ 以上を含む合金 で, $\alpha(\mathrm{W}, \mathrm{Re}, \mathrm{Mo}, \mathrm{Cr}$ の周溶体) 相および $\sigma(\mathrm{Cr}$, W， Re，Moリッチ) 相の析出が認められたという事実 と対応している。従って， $0.40 \mathrm{~mol} \%$ のご微量の $\operatorname{Re}$ 添加により， $\alpha$ 相および $\sigma$ 相が析出したことから, 単純 な合金元素添加量の増加よりも，むしろ Re 添加に起因 する固溶限の変化が大きいと考えられる.

これらの結果を基に各合金元素の分配比, $\gamma_{i} / \gamma^{\prime}{ }_{i}\left(\gamma_{i}\right.$, $\gamma_{i}^{\prime}: \gamma, \gamma^{\prime}$ 相中の $i$ 元素のモル濃度) を計算した。 その 結果を Fig. 7 に示す。ここで， Re は $\gamma^{\prime}$ 相にはほとん ど分配せず， $\gamma$ 相のみに分配したので，便宜上， Re の 分配比に矢印をつけて示した。 Re 量の増加にともな い, W, Mo, Cr の分配比が低下した。ここで, 0.25 mol\%Re 系の TUT201 (Ni-10Cr-12Al-1.2Ti-2.6Ta- 


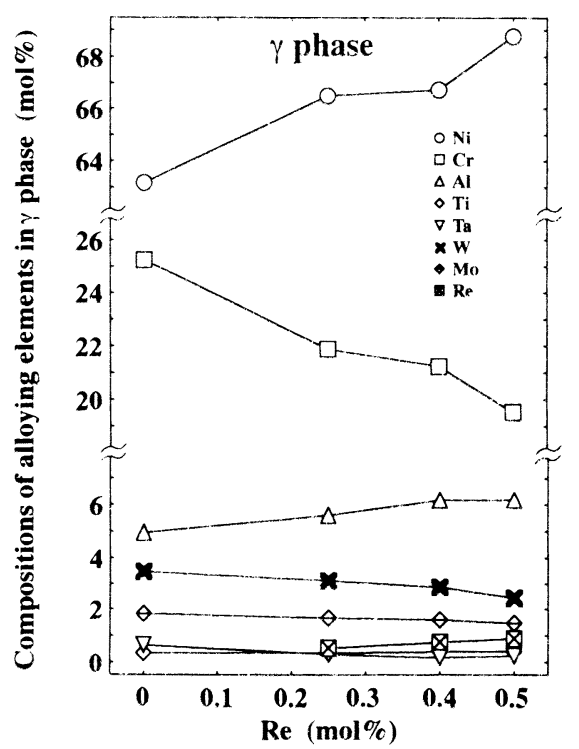

Fig. 5. Chemical compositions of the $\gamma$ phase in the allovs containing various levels of Re content.

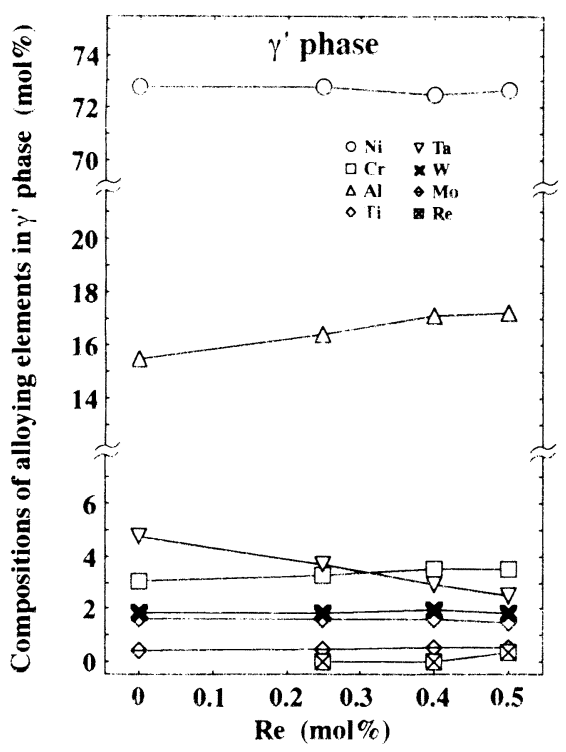

Fig. 6. Chemical compositions of the $\gamma^{\prime}$ phase in the alloys containing various levels of Re content.

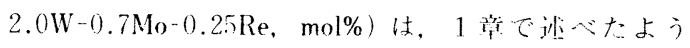

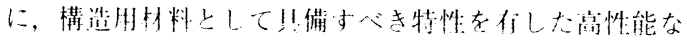

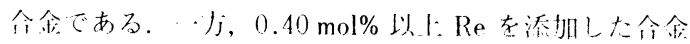

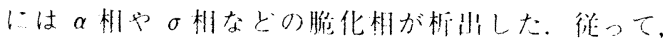

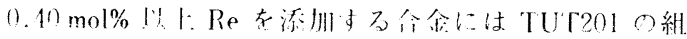

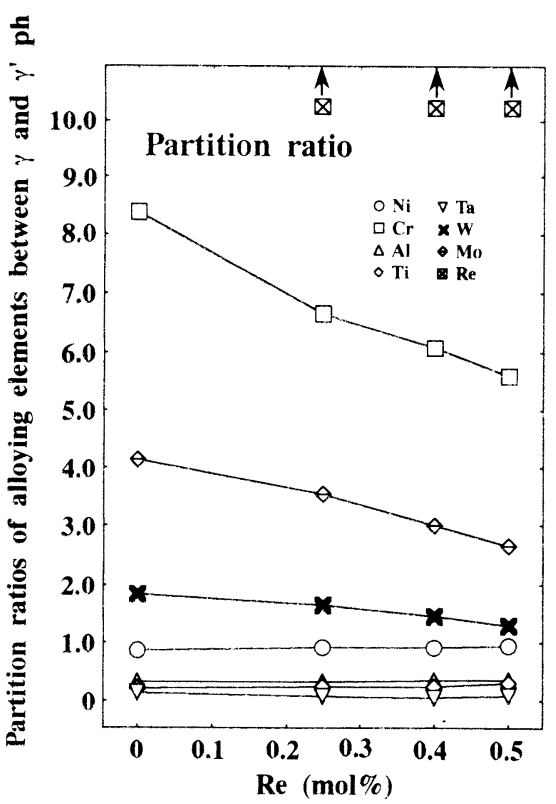

Fig. 7. Change in the partition ratios of elements between the $\gamma$ and the $\gamma^{\prime}$ phases with the Re content of alloys.

戍に比いて Cr，W，Mo 量を減少も甘る必要がある。 さらにRe添加にともない $\gamma$ 相あるいは $\gamma^{\prime}$ 相中で $\Lambda$

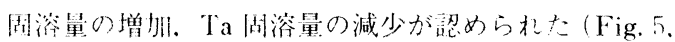
6). 推って，0.40 mol\% 以上: Reを添加するには Cr,

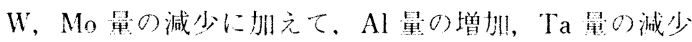
在考えなけ机ばならない。以上にホしたようにRe 添抽 により他の介金元素の分配比が大きく変化することか

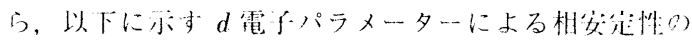

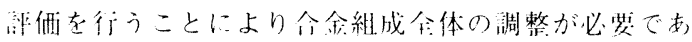

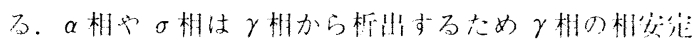
性が車要である。往って、全組成については，薯者ら

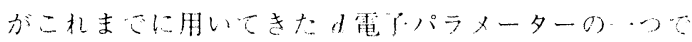

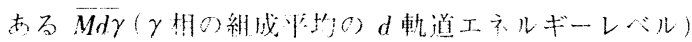

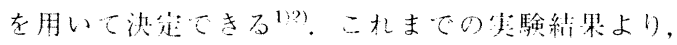
$\overline{M d \gamma} \leqq 0.93$ の条作老満圭声ことにより脆化相の析出は 抑制できることが分か。ている ${ }^{1) 2}$. さらに，其荘 $\gamma^{\prime}$ 相

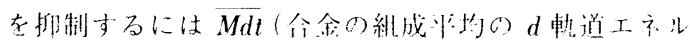

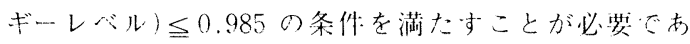

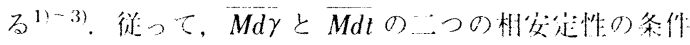

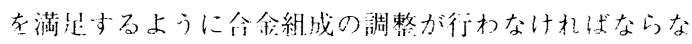
w. 
$3 \cdot 2 \mathrm{Ni}-10 \mathrm{Cr}-12 \mathrm{Al}-1.5 \mathrm{Ti}-2.1 \mathrm{Ta}-2.3 \mathrm{~W}-0.8 \mathrm{Mo}-0.25 \mathrm{Re}$ $-0 / 4.5 / 9.0 C_{0}$ 合金

$3 \cdot 2 \cdot 1 \quad \gamma, \gamma^{\prime}$ 相の組成と合金元素の分配比

Table 2 に組成を示すように, TUT92 およびそ机を

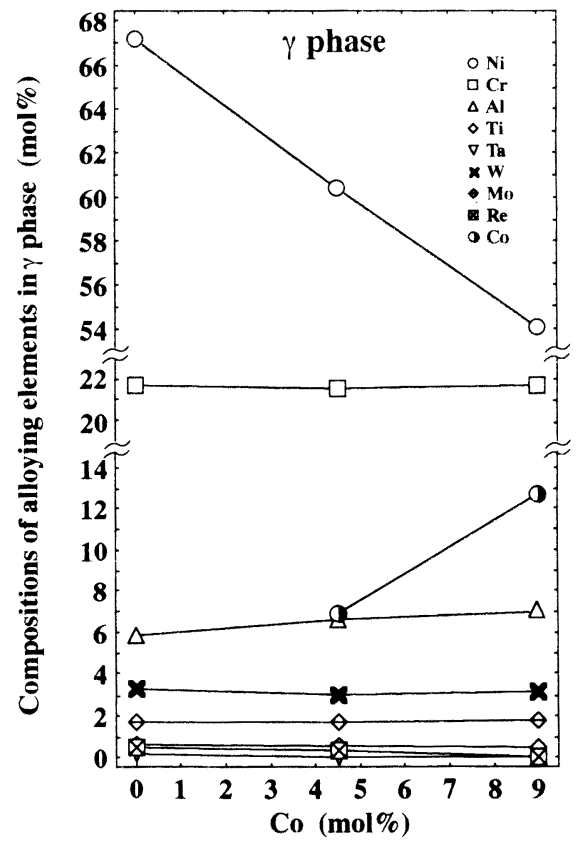

Fig. 8. Chemical compositions of the $\gamma$ phase in the alloys with $0,4.5$ and $9.0 \mathrm{~mol} \%$ Co contents.

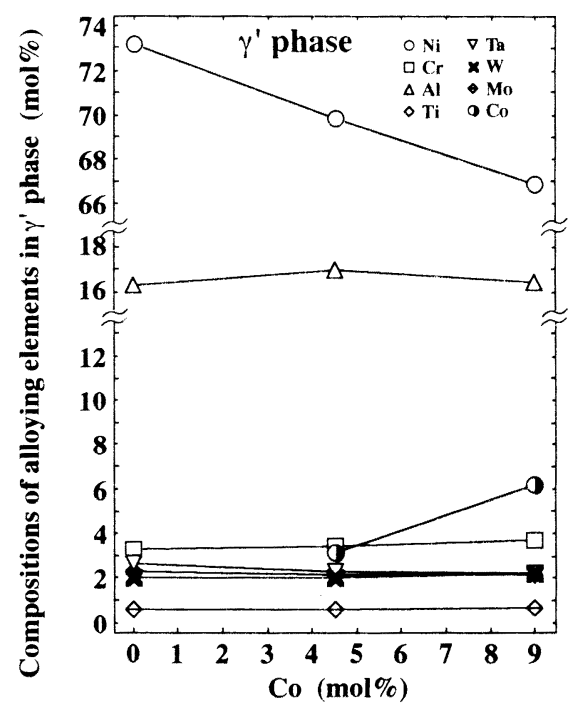

Fig. 9. Chemical compositions of the $\gamma^{\prime}$ phase in the alloys with $0,4.5$ and $9.0 \mathrm{~mol} \%$ Co contents.
基に $\mathrm{Ni}$ とCo をそれぞれ 4.5 抢よび $9.0 \mathrm{~mol} \%$ ずつ置 換した今金（TUT921A，921）についても， $\gamma$ 相抢よび $\gamma^{\prime}$ 相を粗大化させ，おのおのの相の組成分析を行った。 その結果を Fig. 8 抢よびFig. 9 に亦す。全金組成の Co 量が増加すると其に， $\gamma$ 相㧍よび $\gamma^{\prime}$ 相のいずれの 相においてもCoの周溶量が増加し，それにともなって どちらの相に扔いても $\mathrm{Ni}$ の泪溶量が減少した。一灰, $\mathrm{Ni}$, Co 以外の条介金元素の $\gamma$ 相扰よび $\gamma^{\prime}$ 相に対する 湖淮量はほとんど変化しなかった。このことは， $\gamma$ 相打 よび $\gamma^{\prime}$ 相に打いて，Co はほとんどすべて $\mathrm{Ni}$ と置換す ることを示している。落今らは $\mathrm{Ni}_{3} \mathrm{Al}\left(\gamma^{\prime}\right.$ 相)に㧍いて

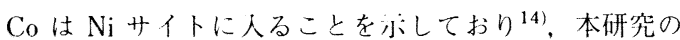
絬果もこの絬果と‥致している.Fig. 10 は，これらを 基に計算した齐令金元素の分酒比の結果である。Fig. 7 と间様に Reはそのほとんどが $\gamma$ 相に分配したので便 䏍上， Reの分配比に矢印をつけて小した。

Co を添加しても条今金元絭の分酒比はほとんど変 化しなかった。従って, Ni-10Cr-12Al-1.5Ti-2.1Ta-2.3W$0.8 \mathrm{Mo}-0.25 \operatorname{Re}(\mathrm{mol} \%)$ 系全金に扔いて，0一9.0 mol\%

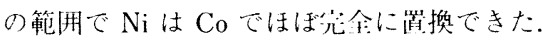

$3 \cdot 2 \cdot 2$ 相安分吽:

4.5 および 9.0 mol\%Co 添㞦介帮(TUT921A, 921)の

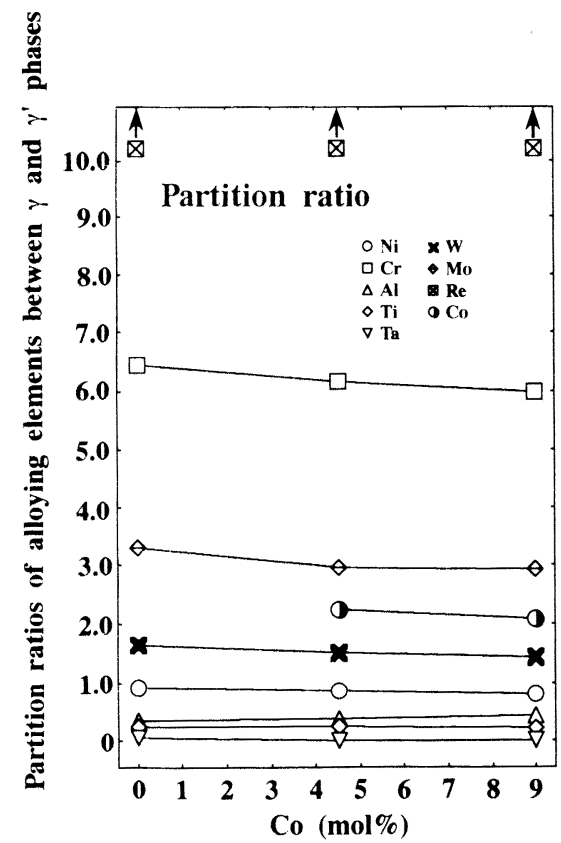

Fig. 10. Change in the partition ratios of elements between the $\gamma$ and the $\gamma^{\prime}$ phases with the Co content of alloys. 
溶体化後に抢ける残留其昆 $\gamma^{\prime}$ 相㫗はTUT92のそ礼

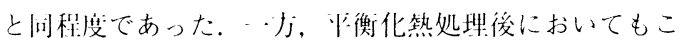
れら介金には脆化析出相は份在せず，相安定性は发好で

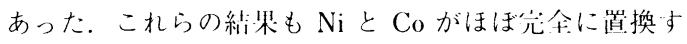
るという絬果（Fig. 8，9）と一效する。これまで仝金の 相安起性は笔子パラメーターの-・つである全金元素の $d$ 軌道エネルギーレベル $(M d)$ と恳い㥊関があることを小 してきた1)-3115). Co と Ni 老置換してもはとんど相㚣 足性が変化しなかったことは恢炎起性を小す電子パラ メーター $(M d)$ が Ni とCoでほぼ等しい(15)ためと考え

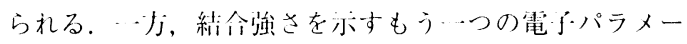
ター $(B o)$ は $\mathrm{Ni} り$ Co のおがわずかに大きい15). 従って， $\mathrm{Ni}^{-} \mathrm{Cr}^{-} \mathrm{Al}-\mathrm{Ti}-\mathrm{Ta}-\mathrm{W}-\mathrm{Mo}-\mathrm{Re}$ 系令金にCo を添

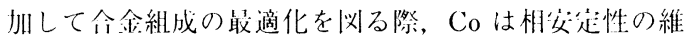

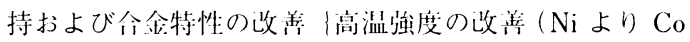
の方が絬合強さが大きい(15)), 酎食性の问上（Coは盰食 性(间上元素泫)\}の観点から，存望な元素であると考え られる。

\section{4. 総括}

Re を会む高性能単絬昆超命金の組成の最適化指針 を得るため, Ni-10Cr-12Al-1.2Ti-2.6 Ta-2.0W-0.7Mo $(\mathrm{mol} \%)$ の 7 元系介食に0〜 $1.00 \mathrm{~mol} \% \operatorname{Re}$ を添加した一 連の合金について，その相安定性を調べると共に，各合 金元素の $\gamma$ 相扩よび $\gamma^{\prime}$ 相への分配比の検封を行った。 またすでに著者らが設計した Re 添加の简性能合金 (Ni-10Cr-12Al-1.5Ti-2.1Ta-2.3W-0.8Mo-0.25Re, mol\%）に0，4.5，9.0 mol\%Co を添加した令金につい ても，その相安定性を淍べると其に条全全元素の分配比 を調べ, $\operatorname{Re}$ 添加全金の組成の最適化という観点から Co の効果を検㴻した。

(1) $\mathrm{Ni}-10 \mathrm{Cr}-12 \mathrm{Al}-1.2 \mathrm{Ti}-2.6 \mathrm{Ta}-2.0 \mathrm{~W}-0.7 \mathrm{Mo} \quad(\mathrm{mol} \%)$ 今金の $\mathrm{Ni}$ と $\operatorname{Re}$ をそれ゙れ $0,0.25,0.40,0.50$, $1.00 \mathrm{~mol} \%$ ずつ置換した仓金に抢ける相䓎走性は，(a) $0.25 \mathrm{~mol} \% \operatorname{Re}$ が其昆 $\gamma^{\prime}$ 相の抑制限界，(b) $0.40 \mathrm{~mol} \%$ $\operatorname{Re}$ が $\alpha$ 抢よび $\sigma$ 相の抑制限界，として整理できる.

(2) Ni-10Cr-12Al-1.2Ti-2.6Ta-2.0W-0.7Mo-0/0.25/ 0.40/0.50Re $(\operatorname{mol} \%)$ 全金に打いて, Reはほとんど $\gamma$ 相中に固浴した。さらに，本合金系に $0.25 \mathrm{~mol} \% よ り$ 多くReを添加した際，命金組成の最適化を汹るために は, Ni-10Cr-12Al-1.2Ti-2.6Ta-2.0W-0.7Mo-0.25Re (mol\%) 合金に比べ, Cr, W, Mo, Ta 量の減少, $\mathrm{Al}$ 量の増加を考えなければならない。

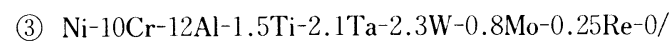

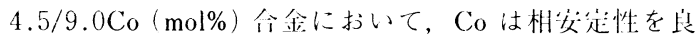

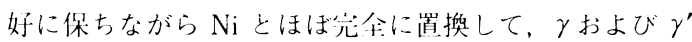
相に湖浴した。な拐，Coを添加しても各们金元素の 分配比は変化しなかった。従って, Ni-Cr-Al-Ti-TaW-Mo-Re 系介金にCoを添加して合金組成の最適化を 刚ることは，茼性能公金を得るうえで有效である。

実験に協力された白井公始技官，横川陸太(当時豊憍 技術科学大学大学院生，現：住友金属鉣山(株)), 川村 泰问（当時豊橋技術科学大学大学院生，現：日本電装 (株)）の各氏に感謝します。本研究は文部省の科学研究 費補助金の一部として行われた。

\section{文献}

1 ) N. Yukawa, M. Morinacia, H. Ezaki and Y. Murata: Proc. Conf. on High Temperature Alloys for Gas Turbines and Other Applications 1986, ed. by W. BET\% et al. (1986), p. 935

$2)$ N. Yukawa, M. Morinagi, Y. Murata, $H$. Ezakl and $S$. INote: Proc. the 6th Int. Symp. on Superalloys, ed. by $D$. N. DuHL et al. (1988), p. 225

3 ) $K$. Matsugi, $R$. Yokoyama, $Y$. Murata, M. Morinacia and $N$. Ylikawa: Proc. Conf. on High Temperature Materials for Power Engineering 1990, ed. by E. BACHELLET et al. (1990), p. 1251

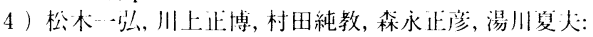
鉄上舢, 77 (1991), p. 1503

5 ) $K$. Matsugi, Y. Murata, M. Morinacia and N. Yukawa: Proc. Int. Conf. \& Exhibition on Computer Applications to Materials Science and Engineering (CAMSE '90), ed. by M. Dorama et al. (1991), p. 831

6) D. Blavette, P. Caron and T. Kahn: Proc. the 6th Int. Symp. on Superalloys, ed. by D. N. DuHL et al. (1988), p. 305

7 ) R. Darolia, D. F. Lahirman and R. D. Field: Proc. the 6th Int. Symp. on Superalloys, ed. by D. N. Dutil et al. (1988), p. 255

8 ) A. D. Critel and D. N. DuHil.: Proc. the 6th Int. Symp. on Superalloys, ed. by D. N. DuHt et al. (1988), p. 235

9 ) D. J. Frasier, J. R. Wiltstonto, $K$. Harris, $G . L$. ERickson and R. E. Schurwr: Proc. Conf. on High Temperature Materials for Power Engineering 1990, ed. by E. BAchel.et et al. (1990), p. 1281

10) M. V. Nathal: NASA Technical Memorandum 83479 (1984) [NASA]

11) NASA Technical Memorandum 83006 , ed. by $J . R$. STEPHENS (1982) [NASA]

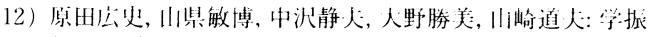
第 123 㫘研究報 ${ }_{1}^{4}, 30(1989)$, p. 251

13) J. J. Jackson, M. J. Donachie, $R$. J. Henricks and $M$. Gfi.l: Metall. Trans. A, 8 (1977), p. 1615

14) S. Ochial, Y. Oya and T. Suzuki: Acta Metall., 32 (1984), p. 289

15) M. Morinagia, N. Yukawa, H. Ezaki and H. Adachi: Phil. Mag. A, 51 (1985), p. 223 